\title{
Phytodegradation potential of bisphenolA from aqueous solution by Azolla Filiculoides
}

\author{
Mohammad Ali Zazouli ${ }^{1}$, Yousef Mahdavi ${ }^{1}$, Edris Bazrafshan ${ }^{2}$ and Davoud Balarak ${ }^{1 *}$
}

\begin{abstract}
Many organic hazardous pollutants such as bisphenolA (BPA) which are toxic and not easily biodegradable can concerns for environmental pollution worldwide. The objective of this study was to examine whether Azolla Filiculoides is able to remove BPA from aqueous solutions. In this study, the Azolla with different biomass $(0.3,0.6,0.9,1.2 \mathrm{~g})$ has been cultured in solution that was contained 5, 10, 25 and 50 ppm BPA. Samples were collected every 2 days from all of containers. The analytical determination of BPA was performed by using of DR4000 uv-visible at $\lambda_{\max }=276 \mathrm{~nm}$. The results indicated that Azolla has high ability to remove BPA from aqueous solutions. The BPA removal was $60-90 \%$. The removal efficiency is increasing with decreasing of BPA concentration and increasing of biomass amount and vice versa. The removal efficiency was more than $90 \%$ when BPA concentration was 5 ppm and amount of biomass was $0.9 \mathrm{gr}$. It is concluded that Azolla able remove BPA by Phytodegradation from the aqueous solutions. Since conventional methods of BPA removal need to high cost and energy, phytoremediation by Azolla as a natural treatment system can decrease those issues and it can be a useful and beneficial method to removal of BPA.
\end{abstract}

Keywords: BisphenolA, Azolla, Industrial wastewater, Phytoremediation

\section{Introduction}

Recently, increasing of endocrine-disrupting chemicals (EDCs) lead to increasing of public concern [1,2]. Bisphenol[2, 2-bis (4'-hydroxyphenyl) propane] is one of such compounds which are used in polycarbonate production, polysulfone, epoxy resins, flame retardant, and also as antioxidant and stabilizer for plastic material, and a compound of food and drink packaging and dental sealants [3-8]. The molecular structure of bisphenolA (BPA) is shown in Figure 1 [9]. The molecular weight and solubility of BPA is $228.1 \mathrm{~g} / \mathrm{mol}$ and $120 \mathrm{mg} / \mathrm{l}$, respectively $[10,11]$. Even in low concentration $(1-10 \mathrm{mg} / \mathrm{l})$, the BPA has many adverse effects on environment and aquatic life such as toxicity on toxicity on algae, invertebrates and fishes $[10,11]$. This compound has harmful effects on human health, including reducing of number and deterioration of sperm quality in males, abnormal or delayed development of male reproductive organs such as retained testis and hypospadias, increasing incidence of prostate cancer, breast cancer and endometriosis with the associated

\footnotetext{
* Correspondence: dbalarak2 @gmail.com

'Department of Environmental Health Engineering, Health Sciences Research Center, Faculty of Health, Mazandaran University of Medical Sciences, Sari, Iran

Full list of author information is available at the end of the article
}

infertility in females $[1,3,10]$. Therefore, the removal from water and wastewater is very important.

Various methods was studied for BPA removal from water and wastewater such as chemical, biological, photochemical, electrochemical, nanofiltration, adsorption, ion exchange, Fenton oxidation, photocatalytic oxidation, bioadsorption, ozonation, and etc. [12-15]. Dong and et al. showed that surfactant-modified zeolite had high retention capacity for BPA in aqueous solutions [16]. Tsai and et al. reported that the adsorption behaviors of microporous zeolite on BPA adsorption greatly depend on the initial BPA concentration and adsorbent dosage [17]. Recently, the phytoremediation is considered as an inexpensive and environmental friend method to remove of heavy metals and degradation of organic compounds [18-21]. Many studies indicated that this method is effective method to remove the organic compound and the removal percentage was more than 99\% [22,23]. The Phytoremediation of organic compounds can take place from the soil, air, groundwater or surface water. The action of plants can include the degradation, adsorption, accumulation and volatilization of compounds or the enhancement of soil rhizosphere activity [24]. Azolla is one of the plants which used to phytoremediation. Azolla is a small free-floating 


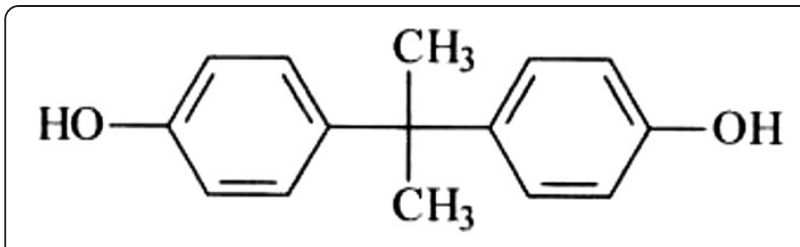

\section{Bisphenol A}

Figure 1 The molecular structure of BPA [9].

water fern which is a genus of Azolla Filiculoides Lam. Because of its habitat and nitrogen-fixing capability, the symbiotic association has been used for several decades as green manure in rice fields [25]. Since this plant is plentiful in northern of Iran and the BPA is common industrial pollutant in the world, therefore the aim of this study was to evaluate the ability of the Azolla for removal of BPA from aqueous solution.

\section{Material and methods Azolla preparation}

A. Filiculoides was collected from rice fields in Sari County, north of Iran. The collected plants were washed with with distilled water to remove unwanted organisms, then transferred into aquariums containing $\mathrm{N}$-free medium of the following composition: $\mathrm{CaCl}_{2} 2 \mathrm{H}_{2} \mathrm{O}, 1.00 \mathrm{mmol} \mathrm{L}^{-1}$, $\mathrm{MgSO} 4.7 \mathrm{H} 2 \mathrm{O} 1.65 \mathrm{mmol} \mathrm{L}^{-1}, \mathrm{~K}_{2} \mathrm{SO}_{4} \quad 0.50 \mathrm{mmol} \mathrm{L} \mathrm{L}^{-1}$, $\mathrm{NaH}_{2} \mathrm{PO}_{4} .2 \mathrm{H}_{2} \mathrm{O} 0.65 \mathrm{mmol} \mathrm{L}^{-1}, \mathrm{FeSO}_{4} .7 \mathrm{H} 2 \mathrm{O} 27.0 \mathrm{mmol} \mathrm{L}^{-1}$, $\mathrm{MnC1}_{2} \cdot 4 \mathrm{H}_{2} \mathrm{O} 1.130 \mathrm{mmol} \mathrm{L}^{-1}, \mathrm{CuSO}_{4} .5 \mathrm{H}_{2} \mathrm{O} 0.080 \mathrm{mmol} \mathrm{L}^{-1}$, $\mathrm{ZnSO} 4.7 \mathrm{H} 2 \mathrm{O} \quad 0.190 \mathrm{mmol} \mathrm{L}^{-1}, \mathrm{Na}_{2} \mathrm{MoO}_{4} \cdot 2 \mathrm{H}_{2} \mathrm{O}$ $0.050 \mathrm{mmol} \mathrm{L}^{-1}$ and $\mathrm{H}_{3} \mathrm{BO}_{3} 5.770 \mathrm{mmol} \mathrm{L}^{-1}$ [22].

Azolla was maintained and grown in laboratory by using of two aquariums with dimensions of $1 \times 0.8 \mathrm{~m}$. five heaters were used to increasing and controlling of temperature for Azolla culture medium. Natural light and ambient temperature $\left(30^{\circ} \mathrm{C}\right)$ was used to Azolla growth [22].The best growth was observed in $\mathrm{pH}$ of 6.5-7.5. It must be mentioned that $\mathrm{CuSO}_{4}$ was used to prevent of algae growth in aquarium.

\section{Lab studies}

All used chemicals in this study were purchased from Merck Co. The 32 plastic containers with the capacity of $200 \mathrm{ml}$ were used as pilot scale to perform the study. Desired concentration of BPA including 5, 10, 25, $50 \mathrm{ppm}$ was prepared by stocks solution (1000 ppm). At first, the culture medium and BPA solution was poured in plastics container and then certain Azolla biomass was added to the containers. Finally, it was allowed to growth of Azolla in containers and to acclimatize with BPA. The certain amount of Azolla was used including 0.3, 0.6, 0.9 and $1.2 \mathrm{~g}$. Also, 8 samples as control sample without plant were used to determine the evaporation of BPA. The BPA concentration was measured by spectrophotometer in certain condition after 4 days of contact time. BPA concentration was determined after of $2,8,12,16$, and 20 days following the exposure.

\section{BPA measurement and analysis}

At first $5 \mathrm{ml}$ of sample was grabbed. It was filtrated after centrifuging for $10 \mathrm{~min}$ in $3600 \mathrm{rpm}$. The filtrated samples were analyzed by uv-visible (DR-4000) at $\lambda_{\max }=276 \mathrm{~nm}$. The removal rate of BPA was determined with regarding to obtained adsorption rates and standard curve [26]. All of the obtained data were analyzed statistically with two or three replicates for their significance. An analysis of variance (ANOVA) was Performed by the software of Spss16. Differences were considered significant when the value was $<0.05$.

\section{Results and discussion}

Effect of temperature on Azolla growth rate

The temperature is one of effective parameter on the growth rate of Azolla. Experimental study of temperature effect on growth rate was performed at the range of $10-50^{\circ} \mathrm{C}$ at $1 \mathrm{~g}$ of biomass. Figure 2 illustrates the effect of the temperature on growth rate of Azolla at a given experimental condition. The better Azolla growth was observed in ambient temperature. Temperatures between 10 to $50^{\circ} \mathrm{C}$ were selected to evaluate of the temperature effect on growth rate of Azolla. The optimum temperature for growth rate of Azolla was observed at $30^{\circ} \mathrm{C}$. As can be observed the amount of Azolla growth was decreased in above and below of $30^{\circ} \mathrm{C}$. These results agree with the other study [27].

\section{Effect of temperature on BPA removal}

The effect of temperature on BPA efficiency removal by Azolla is presented in Figure 3. As shown Figure 3, the experiments were conducted in various temperatures $(20,30$ and $40^{\circ} \mathrm{C}$ ) to assess the effect of temperature on BPA removal by Azolla. The results showed that the optimum temperature to $\mathrm{BPA}$ removal was obtained at $30^{\circ} \mathrm{C}$. The efficiency of BPA removal was declined in below and above of $30^{\circ} \mathrm{C}$. Bisphenol removal was significantly enhanced by

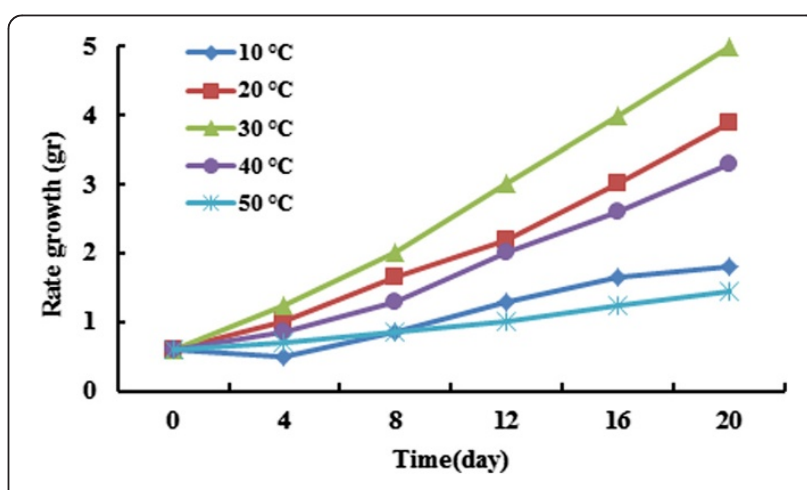

Figure 2 Effect of temperature on Azolla growth (initial biomass = $0.9 \mathrm{~g})$. 


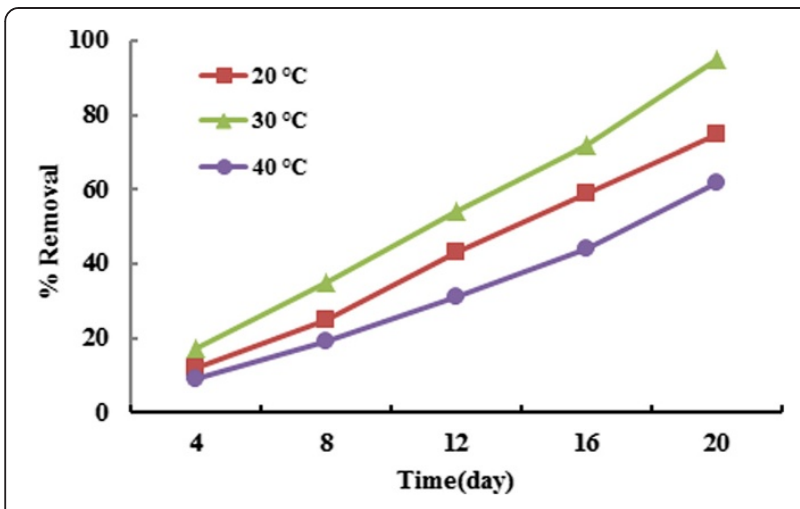

Figure 3 Effect of temperature on BPA uptake by Azolla (initial concentration of BPA $=10 \mathrm{ppm}$, the initial amount of Azolla $=0.9 \mathrm{~g}$ ).

increasing the temperature at 20 to $30^{\circ} \mathrm{C}\left(\mathrm{P}_{\text {value }}<0.001\right)$. Maximum BPA removal observed at $30^{\circ} \mathrm{C}$. This temperature is predominant in north of Iran, specially end of summer and early fall, so that Azolla able to treat polluted water to BPA in sometimes of years. The results of this study agree with the other studies [22,27]. The experiments indicated that the removal efficiency increases by an increase in contact time. It was clear that there is little removal percentage in early days. However it can increase after adapting in environment which is consistent with several studies [28,29]. The high contact time can lead to increase the chance for more contacts between BPA molecules and the plant which this can be considered as a reason for these results [22].

\section{Effect of BPA concentration}

The effect of initial concentration of BPA on removal efficiency is shown in Figure 4. Removal efficiency is reduced by increasing of BPA concentration which this result is agreed with another study [30]. According to the results, the maximum percentage of BPA removal was occurred at the initial concentration of $5 \mathrm{ppm}$; however, there is no significant difference in removal amount in concentrations of 5 and $10 \mathrm{ppm}$. Using the control sample indicated that 15-

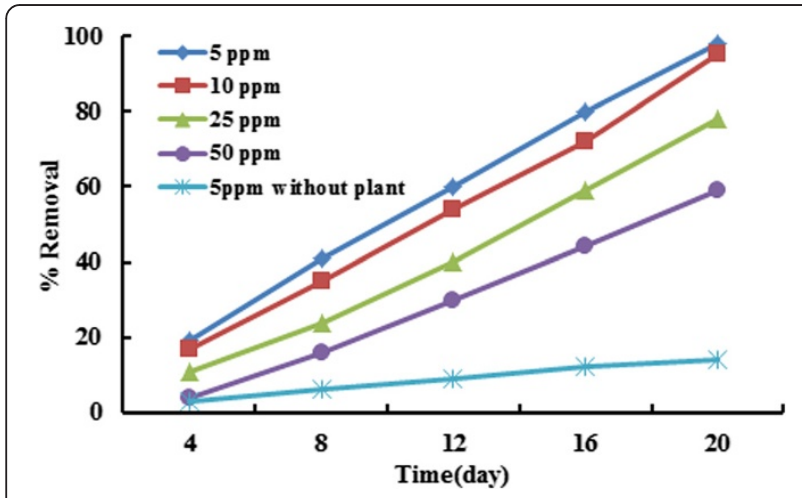

Figure 4 Effect of initial concentration of BPA removal efficiency (initial amount of biomass $=0.9 \mathrm{~g}, \mathrm{~T}=30^{\circ} \mathrm{C}$ ).

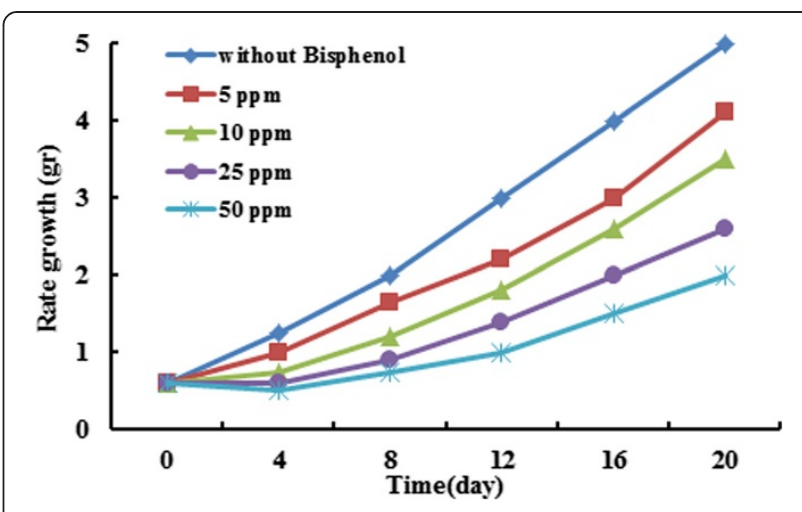

Figure 5 Effect of initial concentrations BPA on inhibition of Azolla growth (Biomass amount $=0.9 \mathrm{~g}, \mathrm{~T}=30^{\circ} \mathrm{C}$ ).

$20 \%$ of BPA were removed by evaporation which it indicated that the actual removal percentage by Azolla was about 75 to $80 \%$. The BPA concentration can influence on Azolla growth, also. The results of BPA concentration on Azolla growth are presented in Figure 5. The growing of Azolla was decreased at concentrations above $50 \mathrm{ppm}$. As it is evident from Figure 5, the growth rate significantly reduced from 20 to $100 \%$ compared to the control ( $\left.P_{\text {value }}<0.001\right)$. Temperature and initial concentration of biomass was kept constant at $30^{\circ} \mathrm{C}, 0.9 \mathrm{~g}$, respectively. Biomass growth rate in absence of BPA is doubled in every four days; however, the growth rate increased every 8 days and 6 days in presence of less and more than $10 \mathrm{ppm}$ of BPA, respectively. The growth rate decreased in presence of more than $50 \mathrm{ppm}$ of BPA concentration, because high concentration of BPA can inhibit the Azolla growth. Inhibitory effects of organic contaminant on Azolla species growth is due to inhibitory effect on photosynthesis, protein synthesis and nitrogen fixation or increase in protease activity have been reported in other studies [31,32]. Also, It was discovered that growth inhibitory effects by the BPA which has not been reported previously. This could be due to decline in photosynthetic pigments [31,32].

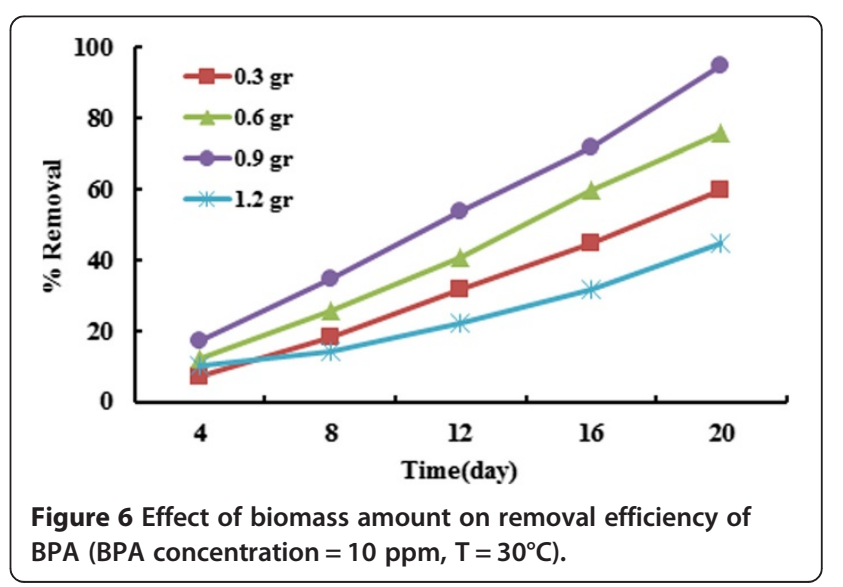




\section{Effect of initial biomass concentration}

Figure 6 is shown the effect of the amount of plant biomass on BPA removal efficiency.BPA removal increased significantly along with an increase in the plant weight $(p<0.001)$. The results indicate that the removal efficiency of BPA was increased by increasing of the amount of Azolla biomass until the entire surface of the containers was not covered. As shown Figure 5, the BPA removal efficiency increased by increasing of plant up to $0.9 \mathrm{~g}$ which it is due to the fact that increasing amount of plant provides more surface area for sorption of the BPA molecule on the surface of plant [33]; however, it decreases in the amount of $1.2 \mathrm{~g}$ of plant because of covering the entire surface of container. There is no worry about the loss of the plant due to abundance of this plant in our country, especially in Bandar Anzali, Miankale Island, paddy field, marsh land and etc. The reasons of great abundance of Azolla is including: Rapid growth, the ability of doubling in short time of the Azolla plant, the resistance of Azolla environmental conditions as well as being multiple layers of this plant and finally strong and developed root system [27].

The uptake pollutants mechanism by plants through the Phytodegradation (also known as phytotransformation) is the breakdown of contaminants taken up by plants through metabolic processes within the plant, or the breakdown of contaminants external to the plant through the effect of compounds (such as enzymes) produced by the plants. Also Mechanism Rhizodegradation is the breakdown of an organic contaminant in soil through microbial activity that is enhanced by the presence of the root zone [34]. Despite the many benefits of phytoremediation, the problems such as measuring phytoremediation rates, predicting treatment times, and developing monitoring schemes are recognized as current limitations to using phytoremediation [24].

\section{Conclusion}

Finally, the results of this study indicated that Azolla have good ability to remove the organic compound from aqueous solution and can give the removal efficiency more than $95 \%$. The Bio removal efficiency depended on the reaction time, initial BPA concentration; fern water weight, $\mathrm{pH}$ and temperature. The conventional methods such as AOP, adsorption and etc., are high cost and consume high energy and because all countries are faced with energy shortage problem today; thus natural systems, for instance use of Azolla, can be good alternative to conventional systems to remove of this compounds from wastewater.

\section{Competing interests}

All authors declare that they have no competing interests.

\section{Authors' contributions}

The overall implementation of this study including design, experiments and data analysis, and manuscript preparation were the results of joint efforts by individuals who are listed as coauthors of this paper. All authors have made extensive contribution into the review and finalization of this manuscript. All authors read and approved the final manuscript.

\section{Acknowledgement}

The authors would like to express their thanks to the research deputy (Student Research Committee) of Mazandaran University of Medical Sciences for its financial support of this study (Project No: 91-181).

\section{Author details}

'Department of Environmental Health Engineering, Health Sciences Research Center, Faculty of Health, Mazandaran University of Medical Sciences, Sari, Iran. ${ }^{2}$ Health Promotion Research Center, Zahedan University of Medical Sciences, Zahedan, Iran.

Received: 20 July 2013 Accepted: 15 March 2014

Published: 2 April 2014

\section{References}

1. Joseph J, Heo J, Park Y, Flora JR, Yoon Y: Adsorption of bisphenol A from aqueous solution onto activated carbons with different modification treatments. Desalination 2011, 281:68-74.

2. Liu G, Ma J, Li B, Qin Q: Adsorption of bisphenol A from aqueous solution onto activated carbons with different modification treatments. Hazard Mater 2009, 164:1275-1280.

3. Belfroid A, Velzen $M$, Horst B, Vethaak D: Occurrence of bisphenol A in surface water and uptakein fish: evaluation of field measurements. Chemosphere 2002, 49:97-103.

4. Bindhumol V, CChitra K, PMathur P: Bisphenol A induces reactive oxygen species generation in the liver of male rats. Toxicology 2003, 188:117-124.

5. Loffredo E, Traversa A, Senesi N: Biodecontamination of water from bisphenol A using ligninolytic fungi and the modulation role of humic acids. Ecotoxicol Environ Saf 2012, 79:288-293.

6. Sajiki J, Yonekubo J: Inhibition of seawater on bisphenol A (BPA) degradation by Fenton reagents. Environ Int 2004, 30:145-150.

7. Staplesa AS, Dorn PB, Klecka GM, O'Block ST, RBranson D, Harris LR: Bisphenol A concentrations in receiving waters near US manufacturing and processing facilities. Chemosphere 2000, 40:521-525.

8. Zhang Y, Causserand C, Aimar P, Cravedi JP: Removal of bisphenol A by a nanofiltration membrane in view of drinking water production. Water Res 2006, 40:3793-3799.

9. Neamt UM, Frimme F: Degradation of endocrine disrupting bisphenol A by $254 \mathrm{~nm}$ irradiation in different water matrices and effect on yeast cells. Water Res 2006, 40:3745-3750

10. Shin HS, Park CH, JPark S, Pyo H: Sensitive determination of bisphenol A in environmental water by gas chromatography with nitrogen-phosphorus detection after cyanomethylation. Chromatogr 2001, 912:119-125.

11. Kusvuran EYD: Degradation of bisphenol A by ozonation and determination of degradation intermediates by gas chromatography-mass spectrometry and liquid chromatography-mass spectrometry. Chem Eng J 2013, 220:6-14.

12. Hideki $K$, Minako M, Shunitz T: Electrochemical removal of bisphenol A based on the anodic polymerization using a column type carbon fiber electrode. Water Res 2004, 38:2331-2338.

13. Karim Z, Husain Q: Application of fly ash adsorbed peroxidase for the removal of bisphenol $A$ in batch process and continuous reactor: Assessment of genotoxicity of its product. Food Chem Toxicol 2010, 48:3385-3390

14. Zhou Y, Lu P, Lu J: Application of natural biosorbent and modified peat for bisphenol a removal from aqueous solutions. Carbohydr Polym 2012, 88:502-508.

15. Zazouli M, Taghavi M, Bazrafshan E: Influences of Solution Chemistry on Phenol Removal From Aqueous Environments by Electrocoagulation Process Using Aluminum Electrodes. J Health Scope 2012, 1(2):66-70.

16. Dong Y, Deyi W, Chen X, Lin Y: Adsorption of bisphenol A from water by surfactant-modified zeolite. J Colloid Interface Sci 2010, 348:585-590.

17. Tsai $W-T$, Hsu H-C, Ting-Yi S, Lin K-Y, Lin C-M: Adsorption characteristics of bisphenol-A in aqueous solutions onto hydrophobic zeolite. J Colloid Interface Sci 2006, 299:513-519.

18. Bennicelli R, Stezpniewska Z, Banach A, Szajnocha K, Ostrowski J: The ability of Azolla caroliniana to remove heavy metals ( $\mathrm{Hg}(\mathrm{II}), \mathrm{Cr}(\mathrm{III}), \mathrm{Cr}(\mathrm{VI}))$ from municipal waste water. Chemosphere 2004, 55:141-146. 
19. Ghorbanzadeh SM, Tajer P, Ghazvini M: Biotechnological potential of Azolla filiculoides for biosorption of Cs and Sr: Application of micro-PIXE for measurement of biosorption. Bioresour Technol 2009, 100:1915-1921.

20. Rakhshaee R, Khosravi M, Ganji MT: Kinetic modeling and thermodynamic study to remove $\mathrm{Pb}(\mathrm{II}), \mathrm{Cd}(\mathrm{II}), \mathrm{Ni}(\mathrm{II})$ and $\mathrm{Zn}(\mathrm{II})$ from aqueous solution using dead and living Azolla filiculoides. Hazard Mater 2006, 134:120-129.

21. Zhao M, Duncan J, Hille R: removal and recovery of zinc from solution and electroplating effluent using azolla filiculoides. Water Res 1999, 33(6):1516-1522.

22. Vafaei F, Khataee AR, Movafeghi A, Salehi Lisar SY, Zarei M: Bioremoval of an azo dye by Azolla filiculoides: Study of growth, photosynthetic pigments and antioxidant enzymes status. Int Biodeterioration Biodegradation 2012, 75:194-200

23. Wang X, Wu N, Guo J, Chu X, Tian J, Yao B, Fan Y: Phytodegradation of organophosphorus compounds by transgenic plants expressing a bacterial organophosphorus hydrolase. Biochem Biophys Res Commun 2008, 365:453-458.

24. Newman LA, Reynolds CM: Phytodegradation of organic compounds. Biotechnology 2004, 15(3):225-230.

25. Forni C, Chen J, Ttancioni I: evaluation of the fern azolla for growth, nitrogen and phosphorus removal from wastewater. Water Res 2001, 35(6):1592-1598.

26. Sui Q, Huang J, Liu Y, Chang X, Ji G, Deng S: Rapid removal of bisphenol A on highly ordered mesoporous carbon. J Environ Sci 2011, 23(2):177-182.

27. Nezamabadi SM: Analysis Research On Technology Management and Water Plant Azolla in Northern Iran Anzali lagoon and wetlands. Agric Sci 2008, 13(2):549-562.

28. Dianati Tilaki RA: Effect Of Glucose And Lactose On Uptake Of By Lemna Minor. Hazard Mater 2010, 7(2):123-128.

29. Peng Ze WF, Deng N: Photodegradation of bisphenol A in simulated lake water containing algae, humic acid and ferric ions. Environ Pollut 2006, 144:840-846.

30. Zazouli MA, Balarak D, Mahdavi Y: Pyrocatechol Removal from Aqueous Solutions by Using Azolla Filiculoides. Health Scopes 2013, 2(1):1-6.

31. Sood A, Pabbi S, Uniyal PL: Effects of paraquat on lipid peroxidation and antioxidant enzymes in aquatic fern Azolla microphylla. Russ J Plant Physiol 2011, 58:667-673.

32. El-Shahate RM, El-Araby MMI, Eweda EW, MN E-B: Evaluation of the effect of three different pesticides on Azolla pinnata growth and NPK uptake. J Am Sci 2011, 7:1020-1031.

33. Khataee AR, Dehghan G, Ebadi A, Zarei M, Pourhassan M: Biological treatment of a dye solution by Macroalgae Chara sp. Effect of operational parameters, intermediates identification and artificial neural network model- ing. Bioresour Technol 2010, 101:2252-2258.

34. Introduction to Phytoremediation: Washington (2000) U. S. Environmental Protection Agency Office of Research and Development; 2000

doi:10.1186/2052-336X-12-66

Cite this article as: Zazouli et al:: Phytodegradation potential of bisphenolA from aqueous solution by Azolla Filiculoides. Journal of Environmental Health Science \& Engineering 2014 12:66.

\section{Submit your next manuscript to BioMed Central and take full advantage of:}

- Convenient online submission

- Thorough peer review

- No space constraints or color figure charges

- Immediate publication on acceptance

- Inclusion in PubMed, CAS, Scopus and Google Scholar

- Research which is freely available for redistribution

Submit your manuscript at www.biomedcentral.com/submit
C Biomed Central 